\title{
Development and validation of an equation to estimate body fat in elderly women
}

\section{Desenvolvimento e validação de uma equação para estimar a gordura corporal em mulheres idosas}

\author{
Vinicius de Oliveira Damasceno ${ }^{1}$ \\ (D) https://orcid.org/0000-0003-0577-9204 \\ Tercio Araújo do Rego Barros ${ }^{2}$ \\ (D) https://orcid.org/ 0000-0001-5111-1593 \\ Willemax dos Santos Gomes ${ }^{1}$ \\ (D) https://orcid.org/0000-0002-3498-9959 \\ Jhonnatan Vasconcelos Pereira Santos ${ }^{1}$ \\ (D) https://orcid.org/0000-0002-3514-558X \\ Daniela Karina da Silva Ferreira' \\ (D) https://orcid.org/0000-0003-1786-7965 \\ Eduardo Zapaterra Campos ${ }^{1}$ \\ (D) https://orcid.org/ 0000-0002-9356-3683 \\ André dos Santos Costa ${ }^{1}$ \\ (D) https://orcid.org/0000-0001-5301-2572
}

Abstract - The purpose of this present study was to develop and validate a prediction equation for body composition assessment using anthropometric measures of elderly women. This is cross-sectional correlational study with 243 older women \pm 64.5 years old and body mass index $(\mathrm{BMI}) \pm 28.70 \mathrm{~kg} / \mathrm{m}^{2}$. For the development of the equation it was utilized the method of hold-out sample validation. The participants were randomly divided into equation development group (96 elderly women) and a group for validation (147 elderly women). Total body mass, height, waist and hip circumferences, ratio waist-hip ratio and BMI were measured. The whole-body dual-energy X-ray absorptiometry (DXA) assessed body composition (percentage of body fat, fat mass, and fat-free mass). The equations were developed using multiple linear regression, with validation by the stepwise method; the comparison of the equations was analyzed by the paired Student's t test and the analysis of residual scores by the method of Blant and Altman. The New Equation presents a strong correlation $(R=0.83)$ and $\left(R^{2}=0.69\right)$, and a standard error of estimation equals to $3.21 \%$ for percentage body fat prediction. The mean difference between the estimations of percentage body fat from DXA and the New Equation was $0.11 \%(t(0,180) ; P=0.850)$. Therefore, the New Equation had an accuracy of $93.5 \%$ and a total error of $1.8 \%$. The body fat estimation in older women using this New Equation based on BMI and age is valid and accurate.

Key words: Aged; Anthropometry; Body composition; Body mass index.

Resumo - O objetivo do presente estudo foi desenvolver e validar uma equação de predição para avaliação da composição corporal utilizando-se medidas antropométricas de idosas. Este é um estudo transversal e correlacional com 243 idosas \pm 64.5 anos de idade e indice de massa corporal (IMC) $\pm 28.70 \mathrm{~kg} / \mathrm{m}^{2}$. Para o desenvolvimento da equação utilizou-se o método de validação hold-out. As participantes foram divididas aleatoriamente em um grupo para desenvolvimento da equação (96 idosas) e um grupo para validação da equação (147 idosas). Massa corporal total, estatura, circunferências da cintura e quadril, relação cintura-quadril e IMC foram mensurados. A absorciometria por raios-X com dupla energia (DXA) para todo corpo foi utilizada para avaliaçấo da composição corporal (percentual de gordura, massa gorda e massa livre de gordura). As equações foram desenvolvidas utilizando a regressão linear múltipla, com validação pelo método stepwise; a comparação das equaçôes foi realizada pelo Teste $T$ para amostras pareadas e análise dos escores residuais por meio do método de Bland e Waltman. A Nova Equação apresentou uma forte correlação $(R=0.83)$ $e\left(R^{2}=0.69\right)$, e uma estimativa de erro padrão de $3.21 \%$ para predição do percentual de gordura. A diferença média entre as estimativas de percentual de gordura pelo DXA e Nova Equação foi de $0.11 \%(t(0,180) ; P=0.850)$. Assim, a Nova Equação teve uma precisão de $93.5 \%$ e um erro total de 1.8\%. A estimativa do percentual de gordura em idosas usando a Nova Equação baseada no IMC e idade são válidos e precisos.

Palavras-chave: Antropometria; Composição corporal; Idoso; Índice de massa corporal.
1 Federal University of Pernambuco. Recife, PE. Brazil.

\section{Faculdade de Comunicação}

Tecnologia e Turismo. Department of Physical Education. Olinda, PE. Brazil

Received: May 07, 2020

Accepted: August 25, 2020

\section{How to cite this article}

Damasceno VO, Barros TAR, Gomes WS Santos JVP, Ferreira DKS, Campos EZ, Costa AS. Development and validation of an equation to estimate body fat in elderly women. Rev Bras Cineantropom Desempenho Hum 2020, 22:e73625. DOI: http://dx.doi.org/10.1590/19800037.2020v22e73625

Copyright: This work is licensed under a $\underline{\text { Creative Commons Attribution }}$ 4.0 International License. 


\section{INTRODUCTION}

The process of aging is related to changes in body composition such as reductions in free-fat mass, bone mineral density, and increases in the percentage of body fat ${ }^{1}$. Changes within these components present an impact in functional capacity, quality of life, and ultimately in mortality risk ${ }^{2,3}$. A common pattern in the elderly population is the predominant increase in visceral body fat most ${ }^{4}$. Noteworthy, weight loss in older adults can accelerate the reductions in fat-free mass and increase the risk of mortality ${ }^{6,5}$. Furthermore, the risk of all-cause mortality in older men with $>5 \%$ loss of weight, lean mass or total fat mass was higher than in elderly who did not have variations in total body fat or weight in a period of at least 3.5 years $^{7}$.

Several methods have been used for body composition evaluation, such as dual-energy X-ray absorptiometry (DXA), bioelectrical impedance, and skinfold and anthropometric measurements ${ }^{8-10,12,11}$. Among these methods, DXA has been considered the "gold standard"; however, it is not available for most populations and has an expensive $\operatorname{cost}^{13}$. On the other hand, skinfold and anthropometric measures have low-cost and easy access for most populations and health professionals, which in turn becomes an alternative for the continued assessments of body composition ${ }^{14}$.

Currently, some prediction equations for the estimation of body composition for older adults have been used, however, most of them have not been developed for the Brazilian population ${ }^{12-14}$. Rech et al. ${ }^{8}$, demonstrated that prediction of percent body fat is dependent of the equation applied, and the only equation developed in Brazil for older women may overestimate this data in $7.2 \%$ compared to the gold standard method (DXA) ${ }^{12}$. Therefore, the purpose of this present study was to develop and validate a prediction equation for body composition assessment using anthropometric measures of elderly women from the city of Recife, PE, Brazil.

\section{METHOD}

\section{Subjects}

In this cross-validation study participants consisted of 243 older women between the ages of 60 and 81 years $( \pm 64.5)$ with body mass index (BMI) ranging from 15 to $46 \mathrm{~kg} / \mathrm{m}^{2}$ ( \pm 28.70$)$. The subjects were recruited from an exercise program called "Healthy Aging" developed by the Physical Education Department from the Federal University of Pernambuco. For the development of the equation it was utilized the method of hold-out sample validation.

The subjects were divided into equation development and validation samples. The sample for equation development consisted of 96 randomly chosen older women from the 243 possible. The sample used for the equation validation comprised of the remaining 147 older women.

Exclusion criteria consisted of older women with age $<60$ years old, and the presence of neurological conditions (neuropathies or use of antipsy- 
chotics drugs) or physical disabilities related to illness (undergoing cancer treatment), as determined by interview prior to data collection.

The ethics committee of the Center of Health Sciences (UFPE) (No. 2.159.115) approved the present study. Written informed consent was obtained from the participants.

\section{Anthropometric measures}

All anthropometric measurements were taken in a single visit to the laboratory. Total body mass was measured to the nearest $0.01 \mathrm{~kg}$ (Filizola, Brazil) and participants were asked to wear light clothing without shoes. Height was measure in a wall-mounted stadiometer to the nearest of 0.01 $\mathrm{m}$. Waist and hip circumferences were measured using an inextensible tape to the nearest of $0.1 \mathrm{~cm}$ (Sanny, Brazil). Waist circumference was taken as the smallest measure between the lowest rib and iliac crest. Hip circumference was measured at the level of the widest circumference over the great trochanters ${ }^{15}$. Waist-hip ratio was calculated dividing the respective circumferences. BMI was calculated in $\mathrm{kg} / \mathrm{m}^{2}$. All measures were taken in triplicate and performed by the same-trained examiner $(>15$ years of experience in anthropometric measures, >1000 anthropometric assessments/year).

The gold standard method to assess body composition (percentage of body fat, fat mass, and fat-free mass) was the whole-body dual-energy X-ray absorptiometry (DXA). For this assessment, participants were instructed to not wear any metallic objects, to lie down in a supine position, and remain quiet without any movement. The procedure lasted between 15-20 minutes. A trained examiner was in charge of calibrating the densitometer, according to manufacturer instructions.

\section{Statistical Analysis}

A bold-out sample validation method was used to develop and test the validity of the New Equation. According to this method, the sample of the present study was divided randomly into two subsamples. The first subsample $(A ; N=96)$ was used to develop a prediction model with the anthropometric variables. The second subsample $(B ; N=147)$ was used to validate and test the accuracy of the New Equation.

Data normality was first checked with the Kolmogorov Smirnov test and Q-Q plots. Descriptive statistics are presented as means, standard deviations, and 95\% confidence intervals (CI). A stepwise forward regression was used to create the model from the anthropometric independent variables (age, total body mass, height, BMI, waist and hip circumference, and waist-hip ratio) with the dependent variable (percentage body fat) $(\mathrm{N}=96)$. A paired sample $t$-test, Pearson's linear correlation $(\mathrm{r})$, and the coefficient of determination $\left(\mathrm{R}^{2}\right)$ were used to analyze the validity of the new equation to predict percentage body fat compared to DXA ( $\mathrm{N}=147)$. Residual scores were analyzed with the Bland \& Altman test. The total error of the new equation was calculated according to Lohman ${ }^{15}$. 


$$
\begin{gathered}
\text { Total error }=\sqrt{\frac{\Sigma\left(y-y^{\prime}\right)^{2}}{N}} \\
\mathrm{y}=\text { measured value; } \mathrm{y}^{\prime} \text { estimated value; } \mathrm{N}=\text { total sample. }
\end{gathered}
$$

An error of $\pm 3,5 \%$ was used to calculate the accuracy of the new equation. All data was analyzed using the software JASP 0.11 for Windows. All graphs were made using the software Graph Prism 6 for Windows. Level of significance was set as $\mathrm{P}<0.05$.

\section{RESULTS}

\section{Development of the New Equation}

Table 1 presents the demographic and anthropometric characteristics data of participants for the development of the new equation (sub-sample A; $\mathrm{N}=96)$. The mean age was 67.16 years $( \pm 4.97)$, mean BMI $29.15 \mathrm{~kg} / \mathrm{m}^{2}$ $( \pm 5.67)$, mean percentage of body fat $43.16( \pm 5.72)$ and $39.04 \mathrm{~kg}( \pm 5.83)$ for mean fat-free mass.

Table 2 shows the stepwise forward linear regression (sub-sample A; $\mathrm{N}$ =96). All anthropometric variables were included (age, BMI, waist and hip circumference, and waist-hip ratio) in the regression, however, only BMI and age presented significant correlations to predict percentage body fat, thus percentage body fat was best estimated by the independent variables age and BMI.

Table 1. Demographic and anthropometric characteristics of participants for equation development $(\mathrm{N}=96)$

\begin{tabular}{lcccccc}
\hline & Mean & SD & Min & Max & $-95 \% \mathrm{Cl}$ & $+95 \mathrm{Cl}$ \\
\hline Age (years) & 67.16 & 4.97 & 60.00 & 81.20 & 66.15 & 68.17 \\
Total body mass $(\mathrm{kg})$ & 69.76 & 14.50 & 34.30 & 112.10 & 66.82 & 72.69 \\
Height $(\mathrm{m})$ & 1.55 & 0.06 & 1.41 & 1.68 & 1.53 & 1.56 \\
BMI $\left(\mathrm{kg} / \mathrm{m}^{2}\right)$ & 29.15 & 5.67 & 15.24 & 46.06 & 28.00 & 30.30 \\
Waist circumference $(\mathrm{cm})$ & 96.20 & 12.23 & 62.00 & 123.00 & 93.72 & 98.67 \\
Hip circumference $(\mathrm{cm})^{\text {Waist-Hip ratio }}$ & 102.92 & 10.89 & 80.00 & 131.00 & 100.71 & 105.13 \\
Percentage of body fat $_{\text {DXA }}$ & 0.93 & 0.06 & 0.78 & 1.14 & 0.92 & 0.95 \\
Fat mass $_{\text {DXA }}(\mathrm{kg})$ & 33.16 & 5.72 & 30.60 & 56.40 & 42.00 & 44.32 \\
Fat-free mass $_{\text {DXA }}(\mathrm{kg})$ & 39.04 & 9.83 & 10.50 & 63.22 & 28.73 & 32.71 \\
\hline
\end{tabular}

Note. SD: standard deviation; Min: minimum; Max: maximum; Cl: confidence interval; BMI: body mass index.

Table 2. Multivariate stepwise forward regression $(N=96)$

\begin{tabular}{lcccccc}
\hline & $\mathrm{b}^{*}$ & Std. Err. & $\mathrm{B}$ & Std. Err. & $\mathrm{t}(93)$ & $\mathrm{p}$-value \\
\hline Intercept & & & 26.3768 & 4.9857 & 5.2905 & 0.0000 \\
BMI $\left(\mathrm{kg} / \mathrm{m}^{2}\right)$ & 0.8153 & 0.0581 & 0.8229 & 0.0586 & 14.0381 & 0.0000 \\
Age (years) & -0.0932 & 0.0581 & -0.1072 & 0.0668 & -1.6047 & 0.1119 \\
\hline
\end{tabular}

Note. Std. Err: standard error; BMI: body mass index. 
The new equation presents $\mathrm{R}=0.83$ and $\mathrm{R}^{2}=0.69$, and a standard error of estimation equals to $3.21 \%$ for percentage body fat prediction. The final equation was percentage body fat $=0.8153^{*}(\mathrm{BMI})-0.0932 *$ (age $)+26.3768$.

\section{Cross-validation of the New Equation}

Table 3 demonstrates the demographic and anthropometric data of participants for the validity of the equation (sub-sample B; $\mathrm{N}=147$ ). Participants had mean age $67.37( \pm 4.77)$ and mean BMI $28.70( \pm 5.28)$.

Table 3. Demographic and anthropometric characteristics of participants for equation validity $(\mathrm{N}=147)$

\begin{tabular}{lcccccc}
\hline & Mean & SD & Min & Max & $-95 \% \mathrm{Cl}$ & $+95 \mathrm{Cl}$ \\
\hline Age (years) & 67.34 & 4.77 & 60.00 & 81.20 & 66.56 & 68.11 \\
Total body mass $(\mathrm{kg})$ & 66.83 & 13.62 & 34.30 & 112.10 & 64.61 & 69.05 \\
Height $(\mathrm{m})$ & 1.52 & 0.06 & 1.36 & 1.68 & 1.51 & 1.53 \\
BMI $\left(\mathrm{kg} / \mathrm{m}^{2}\right)$ & 28.70 & 5.28 & 15.24 & 46.06 & 27.84 & 29.56 \\
Waist Circumference $(\mathrm{cm})$ & 94.30 & 11.93 & 62.00 & 132.00 & 92.35 & 96.24 \\
Hip Circumference $(\mathrm{cm})$ & 101.87 & 10.40 & 80.00 & 133.00 & 100.17 & 103.56 \\
Waist-Hip ratio & 0.93 & 0.07 & 0.61 & 1.14 & 0.91 & 0.94 \\
\hline
\end{tabular}

Note. SD: standard deviation; Min: minimum; Max: maximum; Cl: confidence interval; BMI: body mass index.

Paired $t$-test (sub-sample B, $\mathrm{N}=147$ ) showed no differences in estimations of percentage body fat $((\mathrm{DXA}=42.89 \pm 5.84 \mathrm{vs}$. New Equation $=$ $42.78 \pm 4.52) ;(\mathrm{t}(0.180) ; P=0.850))$, fat mass $((\mathrm{DXA}=29.20 \pm 9.15$ vs New Equation $=29.16 \pm 9.12 ;(\mathrm{t}(0.036) ; P=0.97))$ and fat-free mass (DXA $=37.63 \pm 5.66$ vs New Equation $=37.67 \pm 4.86$; $(\mathrm{t}(-0,063) ; P=0,94))$ from DXA and the New Equation. The mean difference between the estimations of percentage body fat from DXA and the New Equation was $0.11 \%$ $(\mathrm{t}(0,180) ; P=0.850)$. The New Equation had an accuracy of $93.5 \%$ and a total error of $1.8 \%$.

Figure 1 exhibits the linear regression between the estimated values of percentage body fat for the new equation and DXA (criterion method). The correlation is classified as strong $\left(R=0.80 ; R^{2}=0.64 ; p<0.0001\right)$.

Figure 2 shows the Bland Altman diagram with the differences between the percentage of body fat from DXA and New Equation. The standard error presented was $-0.65 \pm 3.63 \%$, therefore it is suggested that new equation overestimates the percentage of body fat from DXA.

\section{DISCUSSION}

The main findings of the present study were: (i) according to the stepwise regression model percentage of body fat was best predicted by the independent variables age and BMI; (ii) the new equation and DXA presented a correlation coefficient and determination coefficient of 0.83 and 0.69 , respectively; (iii) there were no differences in estimation of percentage body fat, fat mass and fat-free mass between the DXA and new equation. 


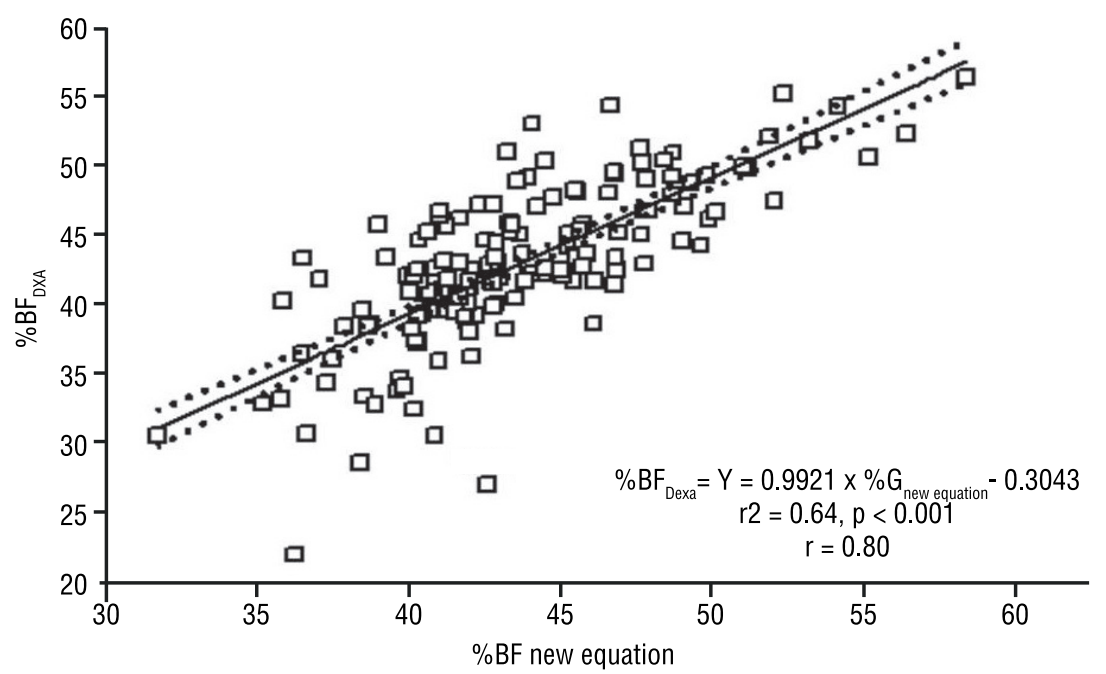

Figure 1. Correlation between estimation of percentage body fat from DXA and new equation. $\% \mathrm{BF}$ : percentage body fat.

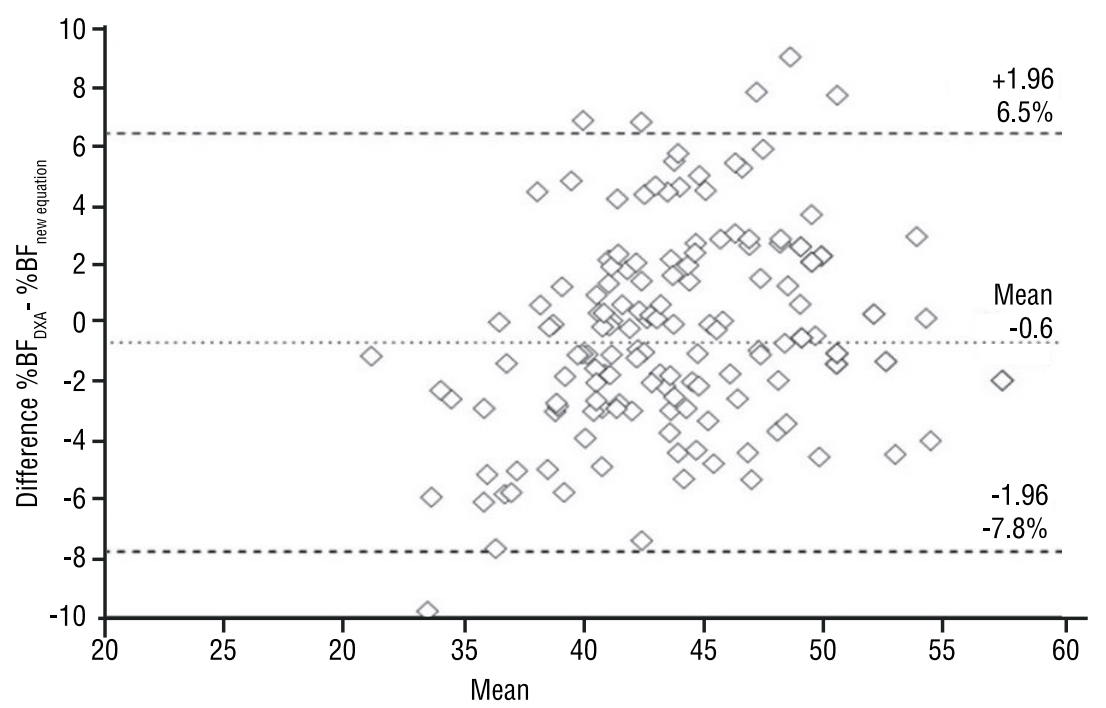

Figure 2. Bland Altman diagram of the difference in percentage body fat as estimated from DXA and new equation. \%BF: percentage body fat.

Body fat prediction for elderly population have been widely used, and equations using anthropometric variables have been shown as an alternative method. Our equation for body fat prediction in older women was only based on BMI and age, and presented a strong correlation $(\mathrm{R}=0.83)$ and determines $69 \%$ of body composition. These results are similar to the equations from Tran and Weltman ${ }^{11}\left(\mathrm{R}=0.88\right.$ and $\left.\mathrm{R}^{2}=0.77\right)$, Deuremberg et al. ${ }^{9}\left(\mathrm{R}=0.89\right.$ and $\left.\mathrm{R}^{2}=0.79\right)$ and Gonçalves et al. ${ }^{12}\left(\mathrm{R}=0.90\right.$ and $\left.\mathrm{R}^{2}=0.81\right)$.

It is noteworthy that only Deuremberg et al. ${ }^{9}$ had developed an equation using only BMI, age and sex, for older adults. Tran and Weltman ${ }^{11}$ utilized a subject sample with ages ranging from 15-79 years old, which is similar to Deuremberg et al. ${ }^{9}$ who opted for development of an equation with ages between 7-83 years old. However, Rech et al. ${ }^{14}$ observed that for Brazilian elderly equations from Tran and Weltman ${ }^{11}$ as well as 
Deuremberg ${ }^{9}$ were not considered as accurate as Gonçalves et al. ${ }^{12}$ who only had subjects with mean age $68 \pm 5.84$ years old.

Our results suggest that new equation was not different from DXA to estimate body composition, besides the acceptable correlation coefficients and standard errors. The new equation showed an accuracy of $93.5 \%$ and mean error was $-0.6 \%$ (95\% CI -7.8 to $6.5 \%$ ) (Figure 2), this variation is lower than what Rech et al. ${ }^{14}$ showed for the equation of Gonçalves et al. ${ }^{12}$ that exhibited a mean error $2.4 \%$ (95\% CI -6.3 to $11.1 \%)$, specifically this equation was the only one developed so far for Brazilian older women.

Compared to previous studies by Deuremberg et al. ${ }^{9}$, Tran and Weltam ${ }^{11}$ and Gonçalves et al. ${ }^{12}$, the new equation appears to be more appropriate for body composition estimation in older women. The new equation is only estimated from BMI and age which are less susceptible to assessment errors instead of skinfold and circumference measures, which are affected by the process of aging $^{3,16}$. BMI is considered a good indicator of body fat in older women whose BMI is higher than $25 \mathrm{~kg} / \mathrm{m}^{2}$, which represents the sample in our study ${ }^{17}$.

It is important to assess body composition during the aging process, for the reason that older adults with a higher gait speed, levels of physical activity and handgrip strength are those associated with lower percentage of body fat ${ }^{18}$. Particularly in women ${ }^{19}$, for the changes related to menopause which are associated with greater concentrations of body fat in the abdominal region and loss of bone mineral density ${ }^{20}$.

This study presents some limitations, first our sample was only constituted of older women and our equation should not be extrapolated to males. Second, subjects in our sample had BMI $>25 \mathrm{~kg} / \mathrm{m}^{2}$, thus we cannot assume that body composition estimation will reach the same results for older women with lower BMI values. Finally, the findings of this study confirm the validity of a new equation for estimation of percentage body fat, fat mass and fat-free mass and confirm its applicability in older women.

\section{CONCLUSION}

Body fat estimation in older women using an equation based on BMI and age is valid and accurate. The New Equation for percentage body fat = $0.8153 *(\mathrm{BMI})-0.0932 *$ (age $)+26.3768$ can be implemented in programs designed to evaluate the physical condition in this specific population.

\section{COMPLIANCE WITH ETHICAL STANDARDS}

\section{Funding}

This research did not receive any specific grant from funding agencies in the public, commercial, or not-for-profit sectors. This study was funded by the authors.

\section{Ethical approval}

Ethical approval was obtained from the local Human Research Ethics 
Committee - Center of Health Sciences (UFPE) and the protocol (no. 2.159.115) was written in accordance with the standards set by the Declaration of Helsinki.

\section{Conflict of interest statement}

The authors have no conflict of interests to declare.

\section{Author Contributions}

Conceived and designed the experiments: ASC and JVPS. Performed the experiments: JVPS. Analyzed the data: VOD. Contributed reagents/ materials/analysis tools: VOD, DKSF, TARB, WSG and EZC. Wrote the paper: VOD, TARD, EZC and WSG.

\section{REFERENCES}

1. Santanasto AJ, Goodpaster BH, Kritchevsky SB, Miljkovic I, Satterfield S, Schwartz AV, et al. Body composition remodeling and mortality: the health aging and body composition study. J Gerontol A Biol Sci Med Sci 2017;72(4):513-9.

2. Chang S-H, Beason TS, Hunleth JM, Colditz GA. A systematic review of body fat distribution and mortality in older people. Maturitas 2012;72(3):175-91.

3. Fantin F, Francesco V Di, Fontana G, Zivelonghi A, Bissoli L, Zoico E, et al. Longitudinal body composition changes in old men and women: interrelationships with worsening disability. J Gerontol A Biol Sci Med Sci 2007;62A(12):1375-81.

4. Goodpaster BH, Krishnaswami S, Resnick H, Kelley DE, Haggerty C, Harris TB, et al. Association between regional adipose tissue distribution and both type 2 diabetes and impaired glucose tolerance in elderly men and women. Diabetes Care 2003;26(2).

5. Newman AB, Yanez D, Harris T, Duxbury A. Weight change in old age and its association with mortality. J Am Geriatr Soc 2001;1309-18.

6. Miller SL, Wolfe RR. The danger of weight loss in the elderly. J Nutr Health Aging 2008;12(7):487-91.

7. Lee CG, Boyko EJ, Nielson CM, Stefanick ML, Bauer DC, Hoffman AR, et al. Mortality risk in older men associated with changes in weight, lean mass, and fat mass. J Am Geriatr Soc 2011;59(2):233-40.

8. Aniteli T, Florindo A, Pereira R, Martini L. Desenvolvimento de equação para estimativa da gordura corporal de mulheres idosas com osteoporose e osteopenia através da espessura de dobras cutâneas tendo como referência absorciometria por dupla emissão de raios X. Rev Bras Med Esporte 2006;12(6):366-70.

9. Deurenberg P, Weststrate JA, Seidell JC. Body mass index as a measure of body fatness: age- and sex-specific prediction formulas. Br J Nutr 1991;65(2):105-114.

10. Dupler TL, Tolson H. Body composition prediction equations for elderly men. J Gerontol A Biol Sci Med Sci 2000;55(3):180-4.

11. Tran ZV, Weltman A. Generalized equation for predicting body density of women from girth measurements. Med Sci Sports Exerc 1989;21(1):101-104.

12. Gonçalves EC, Filho JF, Castro JWB. Equação de regressão com a perimetria para mulheres na terceira idade. Rev Baiana Educ Física 2005;6(1):36-51.

13. Rothney MP, Martin F, Xia Y, Beaumont M, Davis C, Ergun D, et al. Precision of GE Lunar iDXA for the measurement of total and regional body composition in nonobese adults. J Clin Densitom 2012;15(4):399-404.

14. Rech CR, Rodrigo L, Lima A De, Cordeiro BA, Petroski EL. Validade de equações antropométricas para a estimativa da gordura corporal em idosos do sul do Brasil. Rev Bras Cineantropom Desempenho Hum 2010;12(1):1-7.

15. Lohman TG. Skinfolds and body density and their relation to body fatness: a review. Hum Biol 1981;53(2):181-225. 
16. Dey DK, Bosaeus I. Comparison of bioelectrical impedance prediction equations for fat-free mass in a population-based sample of $75 \mathrm{y}$ olds: the NORA study. Nutrition 2003;19(10):858-864.

17. Meeuwsen S, Horgan GW, Elia M. The relationship between BMI and percent body fat, measured by bioelectrical impedance, in a large adult sample is curvilinear and influenced by age and sex. Clin Nutr 2010;29(5):560-6.

18. Falsarella GR, Gasparotto LPR, Barcelos CC, Coimbra IB, Moretto MC, Pascoa MA, et al. Body composition as a frailty marker for the elderly community. Clin Interv Aging 2015;10:1661-1666.

19. Kyle UG, Genton L, Hans D, Karsegard L, Slosman DO, Pichard C. Age-related differences in fat-free mass, skeletal muscle, body cell mass and fat mass between 18 and 94 years. Eur J Clin Nutr 2001;55:663-72.

20. Fragala MS, Clark MH, Walsh SJ, Kleppinger A, Judge JO, Kuchel GA, et al. Gender differences in anthropometric predictors of physical performance in older adults. Gend Med 2012;9(6):445-56.

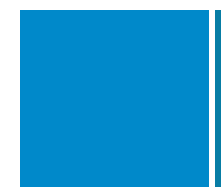

Corresponding author

Vinicius de Oliveira Damasceno

Av. Prof. Moraes Rego, 1235 - Cidade Universitária,

Recife - PE, Brazil - CEP: 50670-901

Email:vinicius.damasceno@ufpe.br 